\title{
Faktor-Faktor yang Menentukan Pemanfaatan Alun-Alun Sebagai Ruang Terbuka Publik di Kabupaten Ngawi
}

\section{Factors Determining the Utilization of Square as a Public Open Space in Ngawi Regency}

\author{
Achmad Fatony ${ }^{\mathrm{a} *}$, Annisa Mu'awanah Sukmawati ${ }^{\mathrm{b}}$ \\ ${ }^{a, b}$ Program Studi Perencanaan Wilayah dan Kota, Universitas Teknologi Yogyakarta, Yogyakarta, Indonesia
}

\begin{abstract}
Abstrak
Penelitian ini berkaitan dengan pemanfaatan ruang terbuka publik yang dapat menampung berbagai aktivitas atau kebutuhan pengunjung pada hari biasa dan hari libur. Penelitian berlokasi di Alun-Alun Kabupaten Ngawi. Perubahan waktu dari pagi hingga sore hari pada hari biasa dan hari libur dapat mempengaruhi pola pemanfaatan Alun-Alun Kabupaten Ngawi. Penelitian bertujuan untuk mengidentifikasi faktor-faktor yang menentukan pemanfaatan alun-alun sebagai ruang terbuka publik di Kabupaten Ngawi. Penelitian menggunakan metode kuantitatif. Pengambilan sampel dilakukan dengan teknik simple random sampling kepada 100 pengunjung. Analisis data dilakukan melalui teknik analisis deskriptif kuantitatif dan analisis pemetaan dengan mapmaker. Hasil penelitian menunjukkan bahwa aktivitas pengunjung pada hari biasa didominasi oleh aktivitas berolahraga dan bersantai. Sedangkan pada hari libur lebih banyak pengunjung yang melakukan berbagai aktivitas dengan rata-rata waktu lebih dari dua jam. Beberapa faktor yang melatarbelakanginya adalah kondisi fisik kawasan dan perilaku pengunjung. Dari kondisi fisik kawasan, pemanfataan alun-alun dipengaruhi oleh kenyamanan, kestrategisan lokasi, dan daya tarik masing-masing zona. Sementara itu, dari segi perilaku pengunjung dipengaruhi oleh ketersediaan waktu luang dan status hubungan sosial pengunjung.
\end{abstract}

Kata kunci: Aktivitas; Alun-Alun Kabupaten Ngawi; Pemanfaatan; Ruang Terbuka Publik.

\begin{abstract}
This research deals with the use of public open spaces that can accommodate various activities or needs of visitors on weekdays and holidays. The research is located in Ngawi District Square. Changes in time from morning to evening on weekdays and holidays can affect the utilization pattern of Ngawi District Square. This study aims to identify the factors that determine the use of the square as a public open space in Ngawi Regency. This research was conducted by using quantitative methods. Sampling was done by using a simple random sampling technique for 100 visitors. Data analysis was performed through quantitative descriptive analysis techniques and mapping analysis with a mapmaker. The results showed that the activity of visitors on weekdays was dominated by sports and leisure activities. Meanwhile, on holidays, there are more visitors who carry out various activities with an average time of more than two hours. Some of the factors which affected it are the physical condition of the each zone and visitor behavior. From the physical condition of each zone, the utilization of the square is influenced by the comfort, strategic location, and attractiveness of each zone. Meanwhile, in terms of visitor behavior, it is influenced by the availability of free time and the social relationship status of visitors.
\end{abstract}

Keywords: Activity; Ngawi Regency Square; Utilization; Public Open Space.

\footnotetext{
* Corresponding author. Achmad Fatony.

E-mail address: afatony280@gmail.com.
} 


\section{Pendahuluan}

Ruang terbuka memiliki fungsi esensial bagi kehidupan manusia. Ruang terbuka tidak hanya berfungsi sebagai ruang sosial, namun juga sebagai ruang ekonomi serta mendukung kelestarian lingkungan. Menurut Hester (1984), ruang terbuka merupakan sebuah perpaduan antara komponen sosial dan fisik suatu lingkungan atau kota. Selain melayani aktivitas sosial, ruang terbuka juga memiliki elemen fisik pembentuk kualitasnya. Di sisi lain, keberadaan ruang terbuka juga menjadi simbol identitas tersendiri bagi sebuah kota karena dapat menampung berbagai aktivitas masyarakat serta menjadi tempat bagi berlangsungnya perayaan tertentu (Anisya \& Muta'ali, 2015; Dianty \& Dwisusanto, 2020).

Carr (1992) mendefinisikan ruang terbuka publik sebagai area umum, dimana orang-orang melakukan aktivitas ritual atau fungsional. Ruang terbuka publik dapat dimanfaatkan oleh pengunjung untuk melakukan berbagai macam aktivitas dan interaksi sosial. Ruang terbuka publik tidak hanya digunakan untuk melakukan aktivitas harian, namun juga aktivitas periodik. Aktivitas harian yang umumnya terjadi, seperti interaksi sosial dan aktivitas ekonomi. Sedangkan aktivitas periodic atau non regular, seperti aktivitas keagamaan dan budaya/ perayaan (Anisya \& Muta'ali, 2015). Ruang terbuka dapat diklasifikasikan menjadi dua, yaitu ruang terbuka aktif yang merupakan ruang terbuka yang di dalamnya terdapat berbagai kegiatan didalamnya, seperti olahraga, bermain, upacara, interaksi, berjalan, dan lain-lain; dan ruang terbuka pasif yang merupakan ruang terbuka yang di dalamnya tidak mengandung kegiatan manusia, seperti penghijauan/ taman sebagai sumber pengudaraan lingkungan, penghijauan sebagai jarak terhadap rel kereta api, dan lain-lain (Hakim, 1987).

Dalam pemanfaatan ruang terbuka publik, pengunjung dapat melakukan berbagai macam kegiatan sesuai dengan kebutuhan pengunjung serta dapat berinteraksi langsung dengan pengunjung lain disekitarnya. Hubungan antara aktivitas pengunjung dan interaksi antar pengunjung sangat erat dalam pemanfaatan ruang terbuka publik. Beberapa penelitian menunjukkan bahwa terdapat beberapa faktor yang mempengaruhi pemanfaatan ruang terbuka publik, seperti aspek kenyamanan (Fathoni \& Purnomo, 2015; Ilmiajayanti \& Dewi, 2015; Sari \& Wahyono, 2015), ketersediaan fasilitas penunjang (Dianty \& Dwisusanto, 2020; Fathoni \& Purnomo, 2015; Ilmiajayanti \& Dewi, 2015), kebersihan (Ilmiajayanti \& Dewi, 2015), kemudahan pencapaian/ aksesibilitas (Dianty \& Dwisusanto, 2020), image dan vitalitas kawasan sekitar (Sari \& Wahyono, 2015).

Dalam perkembangan dan kemajuan infrastruktur pembangunan di Kabupaten Ngawi, pemerintah Kabupaten Ngawi mulai memperkenalkan suatu ruang terbuka publik yang dapat mewadahi berbagai hal aktivitas pengunjung dengan mempertahankan nilai kearifan lokal, budaya, dan sejarah Kabupaten Ngawi. Kabupaten Ngawi memiliki sebuah ruang terbuka publik yang berlokasi di tengah wilayah kabupaten, yaitu Alun-Alun Kabupaten Ngawi. Secara administratif, Alun-Alun Kabupaten Ngawi terletak di Kecamatan Ngawi. Alun-Alun Kabupaten Ngawi memiliki lokasi yang cukup strategis dengan dikelilingi oleh perkantoran, sekolah, masjid agung Kabupaten Ngawi, serta pusat perdagangan. Alun-Alun Kabupaten Ngawi berfungsi sebagai ruang terbuka publik yang dapat dimanfaatkan oleh siapa saja. Oleh karena itu, Alun-Alun Kabupaten Ngawi ramai pengunjung baik dari pengunjung dalam Kabupaten Ngawi maupun pengunjung yang berasal dari luar Kabupaten Ngawi.

Alun-Alun Kabupaten Ngawi yang mempunyai berbagai ruang didalamnya untuk mewadahi aktivitas pengunjung. Ruang tersebut berupa zona olahraga, zona bersantai, zona bermain, zona perdagangan, dan zona untuk acara-acara khusus yang dapat melibatkan interaksi sesama pengunjung. Namun, intensitas pengunjung di Alun-Alun Kabupaten Ngawi senantiasa berubah seiring dengan bergantinya waktu. Hal ini dapat dilihat dari intensitas kunjungan di hari kerja dan hari libur yang berbeda. Bahkan terdapat pula perbedaan pola kunjungan pada waktu pagi, siang, dan malam hari. Selain itu, perubahan intensitas pengunjung pada zona-zona AlunAlun Kabupaten Ngawi juga tidak merata. Ada beberapa tempat atau titik tertentu yang dipadati oleh pengunjung dan ada juga tempat atau titik yang jarang didatangi oleh pengunjung. Hal ini disebabkan oleh beberapa faktor terkait perilaku pengunjung yang mempengaruhi pemanfaatan ruang-ruang pada Alun-Alun Kabupaten Ngawi. Selain itu, kondisi kenyamanan kawasan juga dapat mempengaruhi pemanfaatan sebuah zona. Menurut Carr (1992) hal ini akan mengganggu kualitas dari ruang publik itu sendiri, yaitu dari fungsi responsif dan kebermaknaan ruang publik. 
Penelitian bertujuan untuk menemukan faktor-faktor yang menentukan pemanfaatan Alun-Alun sebagai ruang terbuka publik di Kabupaten Ngawi. Pendekatan place-centered mapping digunakan untuk mengidentifikasi bagaimana tiap individu atau kelompok manusia memanfaatkan dan menggunakan perilakunya dalam suatu situasi waktu dan tempat tertentu (Haryadi \& Setiawan, 2020) agar sebaran pola pemanfaatan aktivitas yang terjadi dapat terlihat secara menyeluruh di kawasan Alun-Alun Kabupaten Ngawi. Secara teoritis, penelitian diharapkan dapat memperkaya khasanah keilmuan di bidang ilmu Perencanaan Wilayah dan Kota, khususnya terkait fungsi ruang publik di sebuah kota melalui identifikasi kondisi pemanfaatan ruang terbuka publik berdasarkan aktivitas, waktu, dan zona pemanfaatannya. Sedangkan secara praktis, penelitian diharapkan dapat menjadi masukkan bagi instansi terkait, yaitu Dinas Pariwisata dan Olahraga Kabupaten Ngawi untuk dapat meningkatkan kualitas dan kenyamanan Alun-Alun terutama pada zona-zona yang sering didatangi pengunjung.

\section{Metode}

Penelitian dilakukan dengan metode penelitian kuantitatif. Metode penelitian kuantitatif dipilih karena penelitian bertujuan untuk menemukenali faktor-faktor yang menentukan pemanfaatan alun-alun sebagai ruang terbuka publik di Kabupaten Ngawi berdasarkan hasil kuesioner kepada pengunjung alun-alun. Hasil analisis akan ditampilkan melalui pemetaan didukung oleh deskripsi-deskripsi.

\subsection{Pengumpulan Data}

Dalam penelitian ini, pengumpulan data dilakukan dengan menggunakan teknik pengumpulan data primer berupa wawancara, kuesioner, dan observasi lapangan. Wawancara dilakukan kepada pihak instansi (Dinas Pariwisata Pemuda dan Olahraga Kabupaten Ngawi) dan beberapa pengunjung Alun-Alun Kabupaten Ngawi untuk menemukenali persepsi pegunjung mengenai kondisi Alun-Alun Kabupaten Ngawi.

Dalam melakukan kuesioner digunakan teknik simple random sampling. Teknik sampling ini ditujukan kepada 100 orang pengunjung alun-alun. Kuesioner digunakan untuk mencari informasi tentang aktivitas pengunjung dan lokasi pengunjung dalam melakukan aktivitas. Sedangkan metode observasi dilakukan untuk mengamati kegiatan langsung pengunjung AlunAlun Kabupaten Ngawi. Observasi dilakukan selama tiga minggu untuk mengamati aktivitas pengunjung pada kondisi waktu yang berbeda, yaitu pada hari kerja (Hari Senin dan Selasa) serta hari libur, yaitu Hari Minggu. Selain itu, juga untuk mengamati aktivitas pengunjung pada pagi, siang, dan malam hari. Observasi dilakukan pada Hari Senin dan Selasa karena merupakan awal minggu dimana diperkirakan aktivitas masyarakat non rekreasi cenderung lebih dominan. Sedangkan hari libur dipilih Hari Minggu karena merupakan puncak pengunjung banyak melakukan aktivitas di pagi hingga malam hari sebagai waktu berakhir pekan baik untuk aktivitas sosial dan rekreasi. Observasi dilakukan selama tiga minggu (22 Februari - 13 Maret 2020) pada tiga waktu yang berbeda, yaitu pagi hari (pukul 07.00-10.00 WIB), siang hari (pukul 11.00-14.00 WIB), dan malam hari (pukul 19.00-22.00 WIB).

Penelitian ini juga menggunakan teknik pengumpulan data sekunder berupa pengumpulan dokumen yang dapat memperkuat hasil analisis. Sumber data dokumen didapatkan dari instansi pengelola Alun-Alun Kabupaten Ngawi, yaitu Dinas Pariwisata Pemuda dan Olahraga (DISPARPORA) Kabupaten Ngawi.

\subsection{Analisis Data}

Analisis dilakukan dengan teknik analisis deskriptif kuantitatif. Data yang terkumpul dari hasil kuesioner, seperti intensitas kunjungan, lama kunjungan, serta hubungan sosial pengunjung akan dikelompokkan dan disajikan dalam bentuk grafik berdasarkan zona terpilih dan waktu agar mudah dipahami.

Peneliti juga akan membuat peta intensitas pengunjung di hari kerja dan hari libur dengan menggunakan aplikasi map maker. Setelah peneliti melakukan observasi intensitas pengunjung menggunakan map maker kemudian file tersebut akan di ekspor ke dalam aplikasi global mapper untuk mengubah format .kml/ kmz menjadi format shapefile (.shp) yang nantinya dapat 
diedit menggunakan aplikasi ArcGIS. Hasil dari peta pola pemanfaatan ruang terbuka AlunAlun Kabupaten Ngawi akan menunjukkan tinggi rendahnya intensitas pengunjung dan aktivitas pengunjung berdasarkan waktu di hari kerja dan di hari libur. Gambar 1 menunjukkan alur analisis data penelitian ini.

\section{Data primer sekunder yang telah dikumpulkan dari hasil survei penelitian \\ Analisis hasil kuesioner dengan mengelompokkan data kebutuhan kemudian disajikan dalam bentuk grafik \\ Analisis wawancara pengunjung untuk memperkuat hasil kuesioner \\ Membuat peta pola pemanfaatan ruang Alun-Alun Kabupaten Ngawi dengan banyaknya aktivitas yang sering dilakukan oleh pengunjung}

Gambar 1. Tahapan Analisis Data (Analisis Peneliti, 2020)

\section{Kajian Literatur}

\subsection{Pemanfaatan Alun-Alun sebagai Ruang Terbuka Publik}

Ruang terbuka publik adalah ruang bersama yang bersifat multifungsi dan tidak dikenakan biaya untuk memasuki dan menggunakan ruang tersebut (Carr, 1992). Ruang terbuka publik dapat digunakan sebagai fungsi sosial, budaya, ekonomi, dan lingkungan alamiah. Lebih lanjut Carr (1992) mengungkapkan bahwa ruang publik yang baik harus memiliki tiga karakter, yaitu bermakna (meaningful) dimana dapat mempertautkan antara manusia dengan kehidupan sosial secara luas, demokratis (democratic) dimana harus dapat digunakan oleh siapa saja/ masyarakat luas, dan responsive (responsive) dimana ruang publik harus mampu mengakomodir berbagai kegiatan penggunanya.

Alun-Alun merupakan salah satu wujud ruang terbuka publik yang menjadi ciri khas masyarakat jawa tradisional. Dalam sejarahnya, Alun-Alun memiliki korelasi dengan keraton yang menjadi pusat sumbu perkembangan sebuah kota yang memperhatikan keseimbangan prinsip kosmologi (Handinoto dalam Susanti, 2015). Untuk itu, dapat dikatakan bahwa alunalun dapat menjadi identitas sebuah kota.

Dalam perkembangannya terdapat perubahan bentuk alun-alun. Perubahan bentuk alunalun ini dapat menggambarkan bahwa pemanfaatan alun-alun belum optimal, dimana cenderung terjadi degradasi fungsi pemanfaatannya. Hal ini dapat disebabkan oleh keterbatasan lahan di perkotaan, kurangnya minat untuk memanfaatkan dan menjaga alun-alun, serta ketersediaan fasilitas alun-alun yang kurang (Hilman, 2015). Padahal, alun-alun sebagai ruang terbuka publik dapat digunakan oleh seluruh kalangan, baik oleh pengguna komersil maupun non komersil (Anisya \& Muta'ali, 2015).

Perkembangan zaman terkait dengan prinsip kuasa, kosmos, dan kultur mempengaruhi perubahan bentuk dan peningkatan fungsi Alun-Alun sebagai ruang terbuka publik (Susanti, 2015). Namun, menurut Indrianingrum et al. (2015), pergeseran fungsi alun-alun dapat terjadi tergantung dari kebijakan pemerintah, misal untuk menunjang fungsi ekonomi. Kondisi ini bisa terjadi sejalan dengan fungsi ruang publik yang dapat bersifat multifungsi dan dapat menampung berbagai aktivitas serta kebutuhan masyarakat melihat posisi strategis alun-alun yang terletak di pusat kota. Untuk itu, guna membangkitkan fungsi alun-alun sebagai ruang terbuka publik, diperlukan langkah untuk mengelola alun-alun secara formal yang dilakukan oleh instansi pemerintah. Selain itu, juga dapat dilakukan dengan memberikan pemahaman bagi masyarakat kota terhadap pemanfaatan alun-alun sebagai ruang publik serta memperbaiki kondisi keruangan dan aksesibilitas (Anisya \& Muta'ali, 2015).

Sebagai salah satu ruang publik, alun-alun yang baik dan fungsional setidaknya memiliki komponen meliputi gerakan/ sirkulasi, desain tempat orang, suasana lingkungan, ruang bagi beragam aktivitas masyarakat, pengendalian fungsi ruang, dan keselamatan serta keamanan (Jamaluddin, 2018). Penelitian Illiyin \& Idajati (2015) menunjukkan bahwa terdapat tiga faktor 
yang mempengaruhi masyarakat dalam memanfaatkan ruang publik, terutama untuk menunjang fungsi sosial, meliputi kondisi aksesibilitas yang baik, kenyamanan dan keamanan, dan daya tarik ruang untuk melakukan berbagai aktivitas. Namun demikian, faktor kenyamanan dan keamanan adalah faktor yang menjadi faktor utama karena berguna untuk menarik pengunjung. Penelitian Susanti (2015) menunjukkan bahwa faktor-faktor yang mempengaruhi pemanfaatan ruang publik, seperti kestrategisan lokasi ruang publik, fungsi bangunan di sekitar ruang publik, desain ruang publik, dan keberadaan peraturan pemerintah yang mengatur fungsi dan penggunaan ruang publik. Sejalan dengan Ilmiajayanti \& Dewi (2015) bahwa pemanfaatan ruang terbuka publik dipengaruhi oleh kelengkapan fasilitas penunjang, keamanan dan kebersihan, dan kesesuaian aktivitas pengguna yang dilakukan di taman. Sari \& Wahyono (2015) juga menunjukkan bahwa variabel kenyamanan terkakit dengan kebersihan dan kelengkapan fasilitas penunjang, kemudahan pencapaian, vitalitas kawasan, dan image alunalun mempengaruhi persepsi pengunjung untuk memanfaatkan alun-alun tersebut.

\subsection{Pertimbangan Standar Penyediaan Ruang Terbuka dan Pemanfaatan Ruang Terbuka}

Ruang terbuka banyak dimanfaatkan oleh masyarakat untuk melakukan berbagai kegiatan di waktu tertentu. Menurut Carmona (2003), ruang terbuka yang ideal merupakan ruang terbuka yang mengandung unsur comfort, relaxation, passive engagement, active engagement, dan discovery.

a. Kenyamanan (Comfort)

Ruang terbuka yang dikatakan berhasil merupakan ruang terbuka yang memiliki fungsi psikologis yang dapat menciptakan rasa nyaman. Lama waktu pengunjung tinggal menjadi tolak ukur tingkat kenyamanan suatu ruang terbuka publik. Hal yang mempengaruhi kenyamanan ruang terbuka publik dapat dilihat dari beberapa aspek lingkungan yang berupa perlindungan dari pengaruh alam seperti sinar matahari; selain itu ketersediaan dan persebaran fasilitas penunjang yang cukup, seperti tempat sampah; tempat duduk, toilet, dan lain-lain.

b. Relaksasi (Relaxation)

Ruang terbuka memiliki hubungan erat terhadap kenyamanan psikologi. Ruang terbuka membentuk kondisi yang dapat menghadirkan unsur-unsur alam, seperti tanaman/pohon yang menyejukan, terhindar dari kebisingan dan hiruk pikuk kendaraan di sekeliling dapat membuat pengunjung merasa rileks dengan pikiran senang.

c. Aktivitas pasif (Passive Engagement)

Aktivitas pasif merupakan aktivitas pengunjung yang tidak banyak melakukan kegiatan, biasanya pengunjung lebih suka melakukan dengan cara duduk-duduk menikmati waktu rileksnya atau pengunjung yang berdiri sambil melihat aktivitas yang terjadi dan pemandangan berupa taman, patung, air mancur di sekelilingnya tergantung dengan kondisi lingkungannya.

d. Aktivitas aktif (Active Engagement)

Aktivitas aktif merupakan kebalikan dari aktivitas pasif. Pengunjung lebih suka memilih melakukan berbagai macam kegiatan seperti olahraga maupun bermain di zona yang sudah ditentukan oleh penataan ruang terbuka tersebut.

e. Pengalaman (Discovery)

Dalam pengelolaan ruang terbuka perlu dilakukan proses untuk membuat aktivitas baru agar aktivitas di dalam ruang terbuka tidak monoton. Aktivitas tersebut dapat berupa acara yang diselenggarakan secara terjadwal maupun tidak terjadwal, seperti konser, pameran seni, pertunjukan teater, festival, dan lain-lain.

\subsection{Karakteristik Pengunjung dalam Penggunaan Ruang Terbuka Publik}

Sesuai dengan fungsi ruang tebuka publik yang mempunyai berbagai macam kegiatan di dalamnya pasti tidak terlepas dari aktivitas pengunjung yang kaitannya dengan perilaku tiap individu dari pengunjung tersebut. Karena sifatnya yang umum, ruang terbuka publik dapat digunakan oleh siapa saja dan untuk siapa saja. Pada umumnya pengunjung melakukan kegiatan sesuai dengan tempat dan lokasi yang telah disediakan, namun masih ada sebagian pengunjung yang melakukan kegiatannya tidak sesuai dengan tempat dan lokasi yang disediakan. Hal ini 
mungkin disebabkan oleh beberapa faktor yang dapat membuat pengunjung merasa kurang nyaman sehingga menjadi tolak ukur keberhasilan dari ruang terbuka tersebut yang umumnya adalah sebagai wadah dari kebutuhan kegiatan pengunjung.

Menurut Smith (dalam Noor, dkk, 2018), karakteristik pengunjung terbagi menjadi dua, yaitu a) Karakteristik sosial ekonomi yang terdiri dari jenis kelamin, usia, asal, dan status pekerjaan; dan b) Karakteristik pola kunjungan terdiri dari tujuan kunjungan, frekuensi kunjungan, teman perjalanan, waktu kunjungan, dan cara melalukan kunjungan. Lebih lanjut menurut Hantono (2017) terdapat korelasi antara pola aktivitas dan pelaku serta pola aktivitas dan waktu. Pola pemanfaatan ruang publik dapat diamati dari siapa pelaku/ pengunjung ruang publik tersebut, pergerakan pengguna, dan waktu kunjungan yang mampu memberikan makna terhadap sebuah tempat. Sejalan dengan Novitasari \& Navastara (2017) bahwa latar belakang kondisi sosial ekonomi dan pola kunjungan dapat mempengaruhi perilaku kunjungan di ruang terbuka publik. Latar belakang sosial ekonomi meliputi usia, jenis, kelamin, pekerjaan, dan pendapatan. Sedangkan pola kunjungan dipengaruhi oleh status pernikahan, frekuensi kunjungan, jarak tempuh, dan ketersediana moda transportasi. Latar belakang kondisi pengunjung dapat mempengaruhi kinerja pemanfaatan ruang terbuka publik.

\section{Hasil dan Pembahasan}

\subsection{Gambaran Alun-Alun Kabupaten Ngawi}

Alun-Alun Kabupaten Ngawi dibangun oleh Dinas Pariwisata Pemuda dan Olahraga (DISPARPORA) Kabupaten Ngawi pada tahun 2015 dengan konsep ruang terbuka publik yang mempunyai banyak manfaat untuk mewadahi kebutuhan pengunjung, seperti olahraga (basket, tenis, futsal, dan sepak bola), rekreasi (taman dan wahana bermain anak), dan kuliner. AlunAlun Kabupaten Ngawi secara Teknis dikelola oleh Unit Pelaksanaan Teknis (UPT) yang secara langsung menurut struktur organisasi dibawah kepala Dinas Pariwisata Pemuda dan Olahraga (DISPARPORA). Unit Pelaksanaan Teknis (UPT) ini bertugas sebagai melayani operasional teknis seperti pengelolaan kebersihan, perbaikan, dan mengawasi kondisi alun-alun. Gambar 2 menunjukkan ilustrasi kondisi Alun-Alun Kabupaten Ngawi.
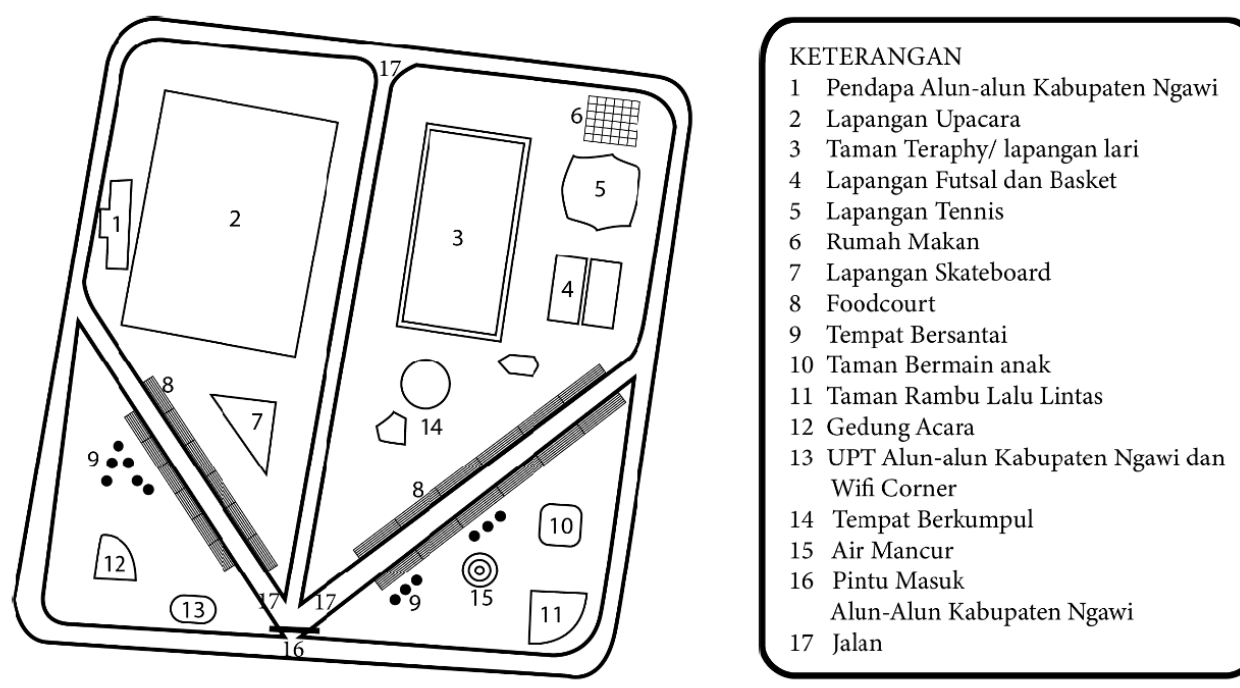

Gambar 2. Ilustrasi Alun-Alun Kabupaten Ngawi (Analisis Peneliti, 2020)

Pemerintah Daerah Kabupaten Ngawi juga mendapatkan pemasukan pendanaan dari hasil sewa lahan di Alun-Alun Kabupaten Ngawi diantaranya sewa lahan kuliner bagi yang ingin mendirikan usaha makanan di Alun-alun Kabupaten Ngawi dan sewa lahan tempat, seperti lapangan yang digunakan untuk mengadakan acara tertentu. DISPARPORA juga menyediakan lahan parkir untuk pengunjung Alun-alun Kabupaten Ngawi. Namun, lahan parkir tersebut masih dikelola oleh warga sekitar dengan biaya parkir Rp 2.000,00 per motor dan $\mathrm{Rp} 5.000,00$ per mobil. 


\subsection{Jenis Aktivitas Pengunjung di Alun-Alun Kabupaten Ngawi}

Pada dasarnya Alun-Alun Kabupaten Ngawi selalu ramai pengunjung baik di hari kerja atau hari libur. Hanya saja pengunjung lebih suka menggunakan fasilitas di zona dan waktu tertentu. Berdasarkan hasil observasi dan wawancara kepada pengunjung Alun-Alun Kabupaten Ngawi, Pengunjung sudah merasa nyaman saat sedang melakukan aktivitasnya di Alun-Alun Kabupaten Ngawi dengan fasilitas yang telah disediakan oleh pengelola Alun-Alun Kabupaten Ngawi. Seperti pada waktu pagi hari, sore hari, dan malam hari baik hari kerja maupun hari libur pengunjung dapat berolahraga, bersantai, dan bermain di Alun-Alun Kabupaten Ngawi. Sedangkan pada siang hari lebih banyak pengunjung yang melakukan aktivitas seperti bersantai dan bermain karena pada zona tersebut memiliki fasilitas seperti pohon peneduh, gazebo, taman, tempat bermain anak-anak, dan lain-lain yang menunjang kebutuhan pengunjung.

Berdasarkan hasil observasi lapangan, jenis aktivitas pengunjung berupa berjalan, duduk, berdiri, mengamati, mengobrol, bermain, dan olahraga. Aktivitas pengunjung di hari kerja dan di hari libur mempunyai perbedaan. Pengunjung Alun-Alun Kabupaten Ngawi di hari kerja dan di hari libur lebih banyak melakukan aktivitas duduk. Sedangkan untuk aktivitas pengunjung yang paling rendah di hari kerja adalah olahraga dan aktivitas pengunjung yang paling rendah untuk di hari libur adalah aktivitas bermain handphone dan aktivitas olahraga.

\subsubsection{Pola Kunjungan Pengunjung Alun-Alun Kabupaten Ngawi}

Frekuensi kunjungan berdasarkan hasil kuesioner menunjukkan bahwa rata-rata pengunjung mengunjungi Alun-alun Kabupaten Ngawi sebanyak satu kali sekali dalam seminggu. Menurut data frekuensi pengunjung Alun-alun Kabupaten Ngawi di hari libur lebih banyak dikunjungi oleh pengunjung daripada di hari kerja. Hal ini disebabkan oleh banyaknya keluarga atau non keluarga yang ingin pergi berlibur untuk merilekskan pikiran atau sekedar bersantai di Alun-alun Kabupaten Ngawi. Gambar 3 menunjukkan grafik perbandingan frekuensi kunjungan antara hari kerja dan hari libur di Alun-Alun Kabupaten Ngawi.

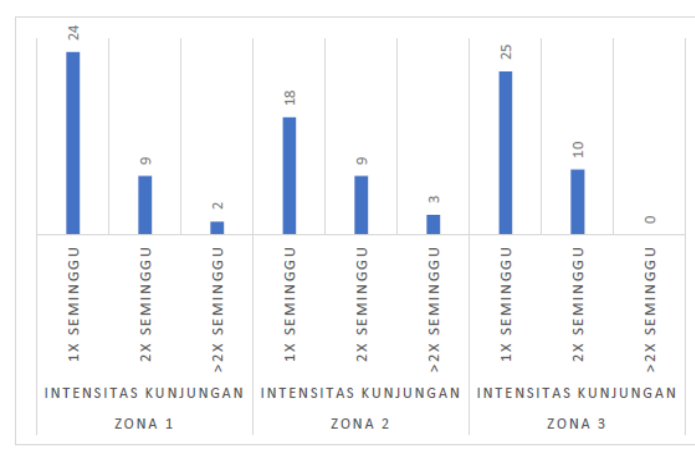

(a)

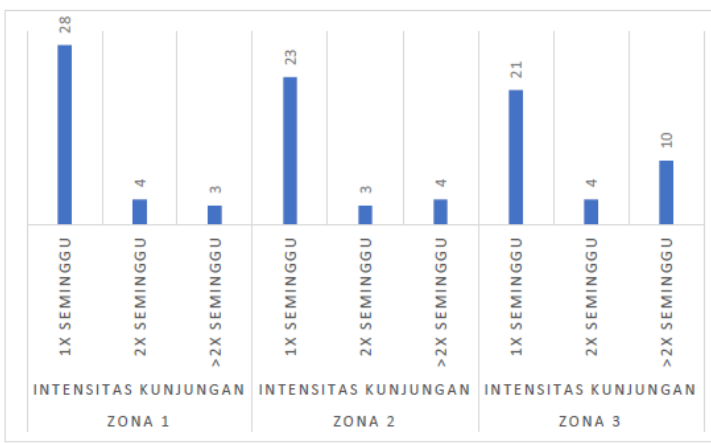

(b)

Keterangan:

Zona 1 = Zona Olahraga

Zona 2 = Zona Bersantai

Zona 3 = Zona Bermain

Gambar 3. Perbandingan Frekuensi Kunjungan di Alun-Alun Kabupaten Ngawi (a) Hari Kerja, (b) Hari Libur (Analisis Peneliti, 2020)

Jika dilihat berdasarkan lama/ intensitas kunjungannya, pada hari kerja pengunjung yang mengunjungi zona olahraga dan bersantai memiliki rata-rata lama kunjungan 1-2 jam sedangkan pada zona bermain memiliki lama kunjungan lebih dari 2 jam. Berbeda dengan hari libur, pada hari kerja pengunjung yang mengunjungi zona olahraga dan bermain memiliki lama kunjungan 1-2 jam sedangkan di zona bersantai lama kunjungan lebih dari 2 jam. 
Latar belakang kebutuhan pengunjung mempengaruhi lama kunjungan. Jika pada hari kerja pengunjung banyak yang memanfaatkan ruang Alun-Alun Kabupaten Ngawi sebagai tempat istirahat atau berolahraga sehingga tidak banyak waktu yang dibutuhkan oleh pengunjung atau dapat dikatakan menggunakan dengan waktu secukupnya. Sedangkan jika pada hari libur pengunjung lebih banyak memiliki waktu luang sehingga berpengaruh ke intensitas kunjungan yang lebih lama. Gambar 4 menunjukkan grafik perbandingan lama kunjungan antara hari kerja dan hari libur di Alun-Alun Kabupaten Ngawi.

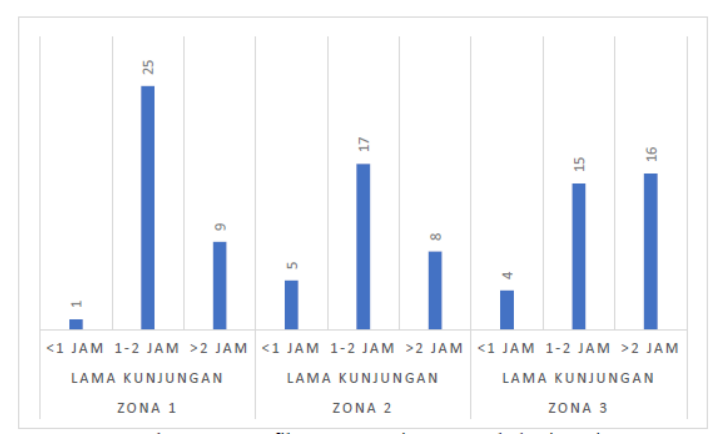

(a)

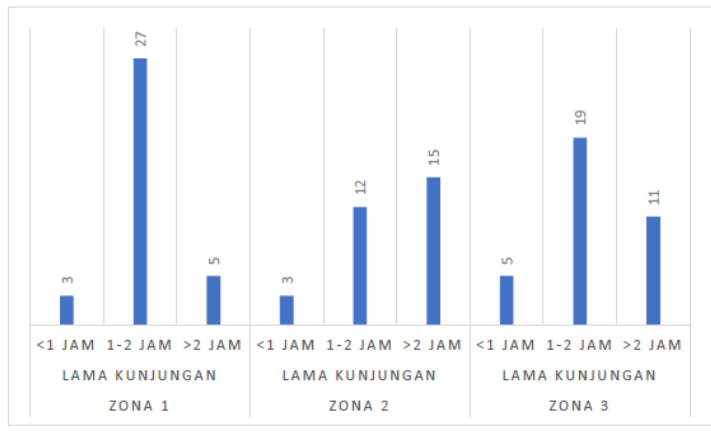

(b)

Keterangan:

Zona 1 = Zona Olahraga

Zona 2 = Zona Bersantai

Zona 3 = Zona Bermain

Gambar 4. Perbandingan Lama Kunjungan di Alun-Alun Kabupaten Ngawi (a) Hari Kerja, (b) Hari Libur (Analisis Peneliti, 2020)

Status hubungan sosial juga mempengaruhi pola kunjungan. Dalam penelitian ini peneliti mengelompokkan hubungan sosial pengunjung menjadi keluarga dan non keluarga. Pada hari kerja diketiga zona tersebut baik zona olahraga, zona bersantai, dan zona bermain didominasi oleh pengunjung yang mempunyai hubungan sosial non keluarga. Sama dengan hasil hubungan sosial pada hari libur, di hari libur juga didominasi oleh pengunjung yang mempunyai hubungan sosial non keluarga. Grafik perbandingan kondisi hubungan sosial pengunjung pada hari kerja dan hari libur terlihat di Gambar 5.

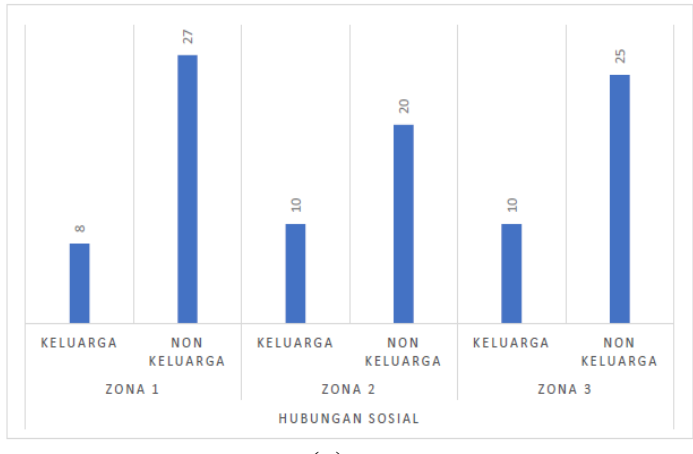

(a)

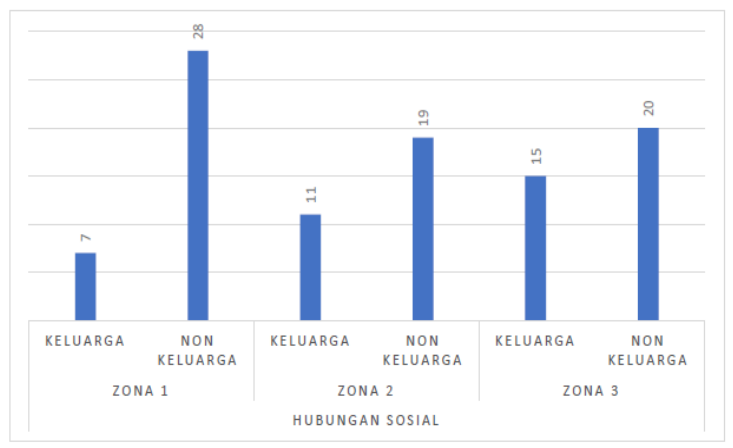

(b)

Keterangan:

Zona 1 = Zona Olahraga

Zona 2 = Zona Bersantai

Zona 3 = Zona Bermain

Gambar 5. Perbandingan Hubungan Sosial Pengunjung Alun-Alun Kabupaten Ngawi (a) Hari Kerja, (b) Hari Libur (Analisis Peneliti, 2020)

\subsection{Pola Pemanfaatan Alun-Alun Kabupaten Ngawi}

Analisis pola pemanfaatan Alun-Alun Kabupaten Ngawi dilakukan dengan mengelaborasikan antara banyaknya aktivitas pengunjung, hubungan sosial intensitas kunjungan, dan frekuensi kunjungan pada hari kerja dan hari libur di waktu pagi hari, siang hari, 
dan malam hari. Analisis ini bermanfaat untuk mengetahui kecenderungan perilaku pengunjung berdasarkan zona-zona yang tersedia. Pemetaan pola pemanfaatan dilakukan dengan mengamati berbagai macam aktivitas pengunjung, yakni berolahraga, bersantai, dan bermain yang diamati pada 3 zona, yaitu zona olahraga, zona bermain, dan zona bersantai.

Gambar 6 memperlihatkan peta pola pemanfaatan Alun-Alun Kabupaten Ngawi dan persebaran pengunjung pada pagi hari. Gambar 6 menunjukkan bahwa terdapat perbedaan pola pemanfaatan antara hari kerja dan hari libur di pagi hari. Pengunjung alun-alun yang melakukan aktivitas di hari kerja baik pada zona olahraga, zona bersantai, dan zona bermain sangat sedikit dibanding dengan pengunjung yang melakukan aktivitas pada hari libur. Kemudian jika dilihat dari intensitas pengunjung dan lama kunjungan, cenderung sama. Hanya saja pada hari libur di zona bersantai lama kunjungan mempunyai jam kunjungan cukup lama rata-rata lebih dari dua jam. Hal ini dikarenakan banyak pengunjung yang memanfaatkan zona bersantai sebagai tempat atau fasilitas yang nyaman untuk menikmati cuaca pagi hari sambil menikmati pemandangan taman-taman bunga di sekitar alun-alun.

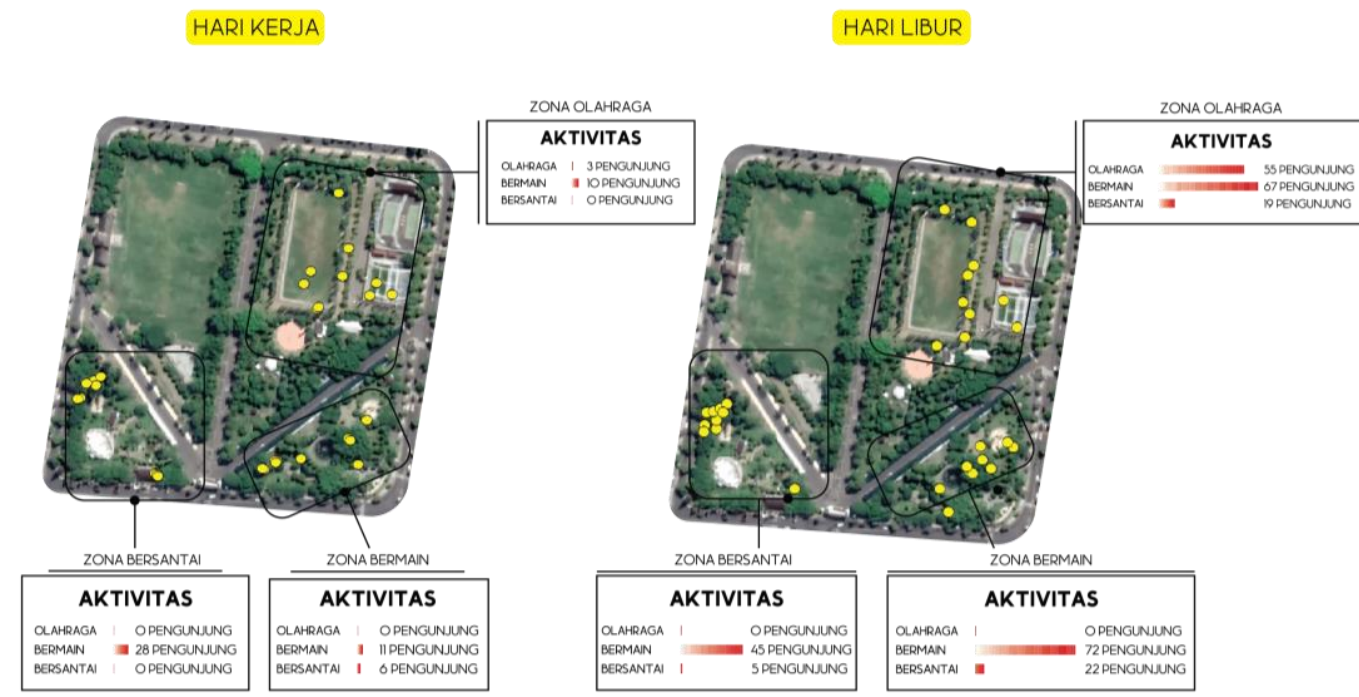

(a)

(b)

Gambar 6. Pola Pemanfaatan Alun-Alun Kabupaten Ngawi pada Pagi Hari (a) Hari Kerja, (b) Hari Libur (Analisis Peneliti, 2020)

Gambar 7 menunjukkan peta pola pemanfaatan Alun-Alun Kabupaten Ngawi dan persebaran pengunjung pada siang hari. Pada siang hari, jumlah dan aktivitas yang dilakukan pengunjung berbeda dengan waktu pagi hari. Kemudian intensitas kunjungan pengunjung pada siang hari di hari kerja dan hari libur rata-rata satu kali dalam seminggu. Pada hari kerja lama kunjungan rata-rata satu sampai dua jam di zona olahraga, bersantai, dan bermain. Berbeda dengan hari libur banyak pengunjung yang menghabiskan waktunya lebih dari dua jam di zona bersantai dan zona bermain.

Gambar 8 menggambarkan peta pola pemanfaatan Alun-Alun Kabupaten Ngawi dan persebaran pengunjung pada malam hari. Pada malam hari banyak pengunjung yang mengunjungi alun-alun baik pada hari kerja maupun hari libur. Aktivitas dominan yang dilakukan oleh pengunjung adalah aktivitas bermain di semua zona. Hal ini dikarenakan pada malam hari Alun-Alun Kabupaten Ngawi banyak pedagang kaki lima yang menjual banyak jajanan dan menyewakan beberapa mainan untuk anak-anak. Intensitas kunjungan pada malam hari di hari kerja rata-rata pengunjung sekali dalam seminggu. Sedangkan intensitas kunjugan pada hari libur pengunjung mengunjungi alun-alun zona olahraga dan zona bersantai seminggu sekali dan pada zona bermain rata-rata berkunjung dua kali dalam seminggu. Untuk lama kunjungan pengunjung di malam hari pada hari kerja mempunyai rata-rata satu sampai dua jam. Sedangkan pada hari libur pengunjung memiliki rata-rata lama kunjungan satu sampai dua jam di zona olahraga dan zona bermain. 


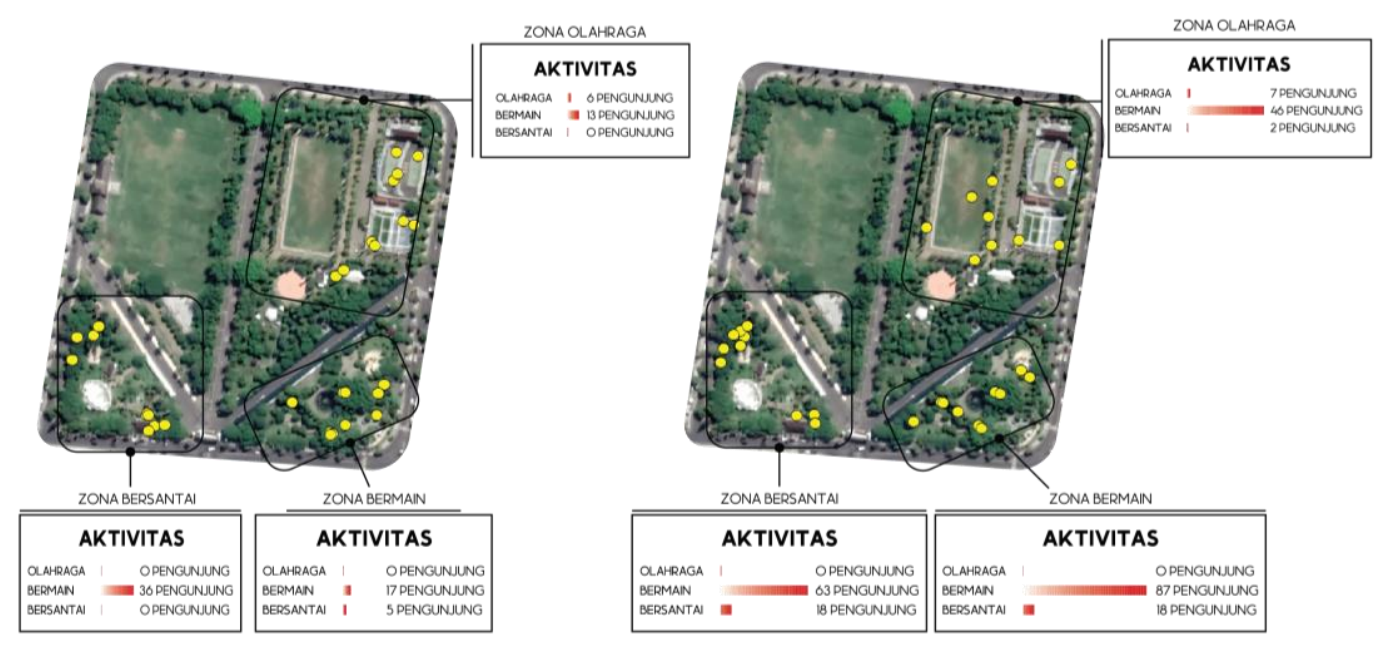

(a)

(b)

Gambar 7. Pola Pemanfaatan Alun-Alun Kabupaten Ngawi pada Siang Hari (a) Hari Kerja, (b) Hari Libur (Analisis Peneliti, 2020)

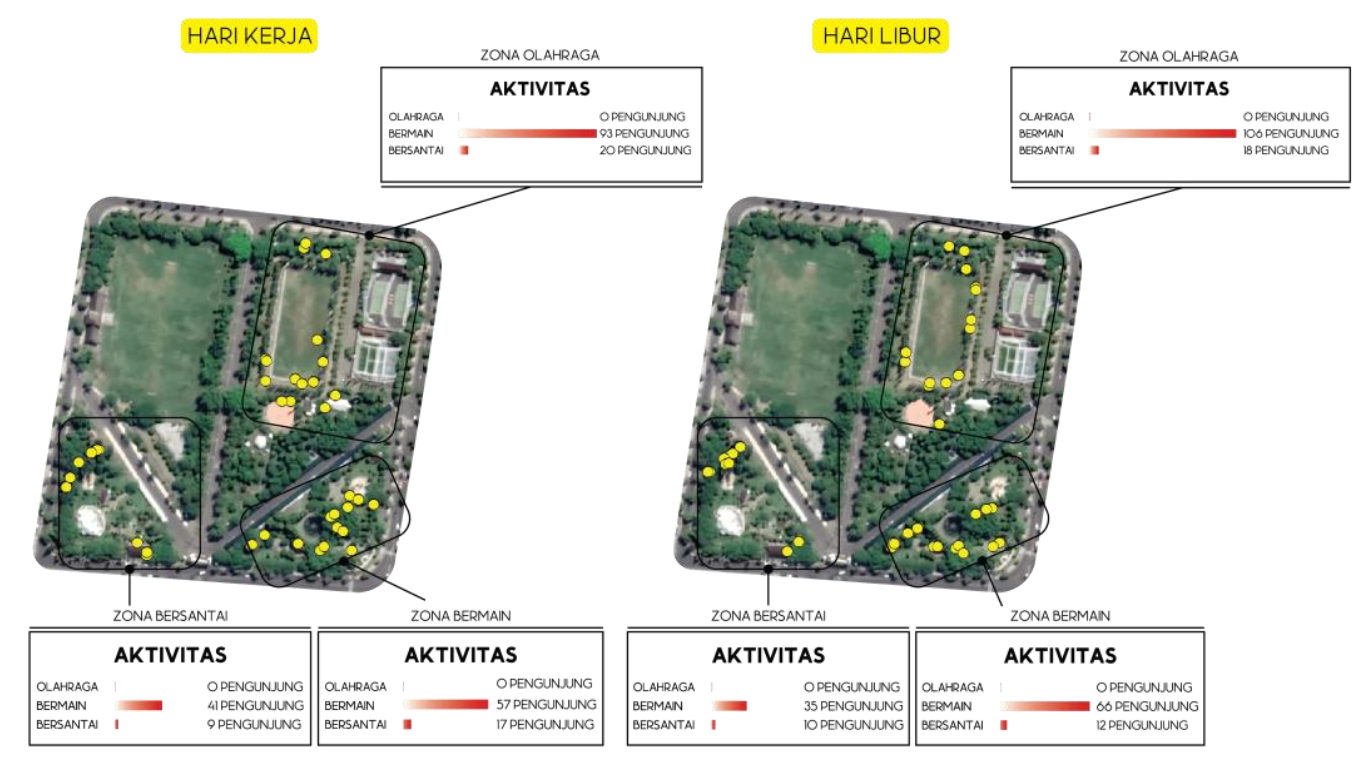

(a)

(b)

Gambar 8. Pola Pemanfaatan Alun-Alun Kabupaten Ngawi pada Malam Hari (a) Hari Kerja, (b) Hari Libur (Analisis Peneliti, 2020)

Gambar 9 menunjukkan perbandingan antara banyaknya aktivitas pengunjung, hubungan sosial intensitas kunjungan, dan frekuensi kunjungan pada hari kerja dan hari libur. Pada hari kerja, zona yang paling banyak dikunjungi oleh pengunjung merupakan zona olahraga dengan aktivitas dominan adalah bersantai $(80 \%)$. Hal ini dikarenakan pengunjung yang melakukan aktivitas olahraga pada saat pagi hari merupakan siswa-siswi yang lokasi sekolahannya berada di sekitar Alun-alun Kabupaten Ngawi. 
Zona kedua yang lebih banyak dikunjungi oleh pengunjung adalah zona bermain. Aktivitas yang dilakukan pengunjung sudah sesuai dengan fasilitas dan pemanfaatan zona yang sudah disediakan yaitu aktivitas bermain dengan persentase $92 \%$. Hal ini karena banyaknya pengunjung yang memanfaatkan zona tersebut sebagai tempat istirahat, bermain mendampingi anak-anak, atau tempat untuk menunggu bagi pengunjung yang sedang bekerja sebagai tukang becak atau ojek online. Zona bermain dirasakan oleh pengunjung lebih fleksibel digunakan baik sebagai lokasi bermain, bersantai, dan menikmati pemandangan sekitar. Sedangkan pada zona bersantai walaupun pengunjung tidak sebanyak zona olahraga dan zona bermain, akan tetapi pengunjung yang sedang melakukan aktivitas bersantai bisa memaksimalkan aktivitasnya dengan intensitas kunjungan seminggu sekali dan durasi lama kunjungan lebih dari dua jam.

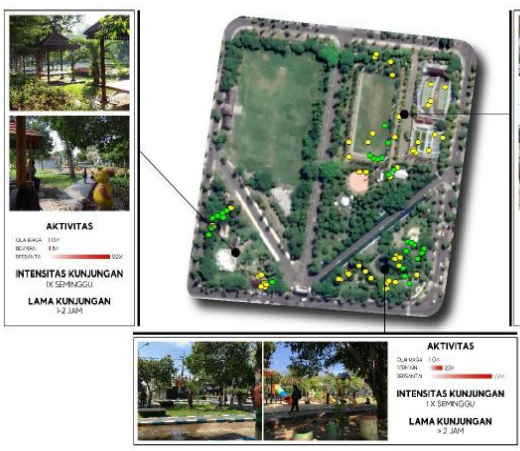

(a)

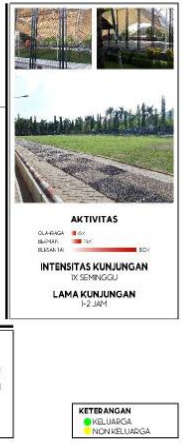

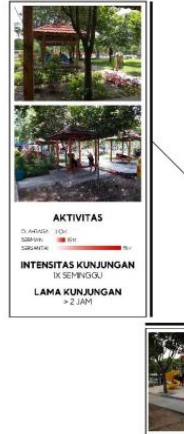

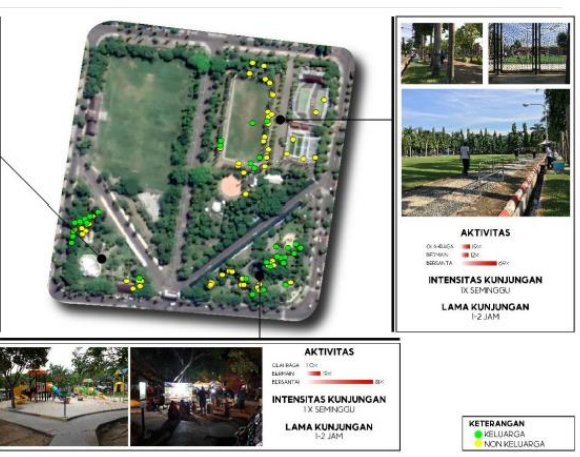

(b)

Gambar 9. Perbandingan Pola Pemanfaatan Alun-Alun Kabupaten Ngawi (a) Hari Kerja, (b) Hari Libur (Analisis Peneliti, 2020)

Berdasarkan peta pola pemanfaatan ruang Alun-Alun Kabupaten Ngawi tersebut, pada hari kerja dan hari libur di zona olahraga lebih banyak pengunjung yang menggunakan ruang tersebut sebagai tempat bersantai dengan duduk di sekeliling lapangan olahraga melakukan aktivitas seperti mengobrol, bermain handphone, makan, minum, melihat pengunjung lain yang sedang melakukan aktivitas olahraga, dan lain-lain. Latar belakang kebutuhan pengunjung berdasarkan kesediaan waktu luang dan status hubungan sosial pengunjung mempengaruhi perilaku kunjungan. Kondisi ini sejalan dengan pendapat Novitasari \& Navastara (2017) bahwa kondisi pekerjaan dan pasangan interaksi mempengaruhi pemanfaatan ruang terbuka publik. Adanya latar belakang kesediaan waktu luang karena kondisi pekerjaan serta kebutuhan aktivitas, seperti kebutuhan aktivitas rekreasi dan relaksasi di akhir pekan menjadikan intensitas kunjungan lebih lama. Berbeda dengan hari kerja, terutama di awal minggu yang mana pengunjung masih sibuk dengan pekerjaan sehingga memiliki waktu luang sedikit.

Di sisi lain jika dilihat berdasarkan kondisi fisik alun-alun, pemanfataan dipengaruhi oleh faktor kenyamanan, kestrategisan lokasi, dan daya tarik zona. Kenyamanan dapat dilihat dari keberadaan fasilitas peneduh serta fungsi zona/ ruang yang dapat menampung beragam aktivitas menjadikan zona olahraga dan bermain menjadi zona favorit lokasi kunjungan. Kestrategisan lokasi dapat dilihat dari lokasinya yang dekat dengan akses pintu masuk maupun lokasi parkir serta keberadaan penjaja kuliner di sekitar zona. Sedangkan daya tarik dapat dilihat dari keberadaan atraksi pemandangan yang lebih baik, seperti air mancur menjadikan zona olahraga dan bermain lebih sering dikunjungi dibandingkan zona bersantai yang lokasinya berdekatan dengan kantor pengelola. Kondisi ini mengkonfirmasi beberapa penelitian sebelumnya bahwa faktor kenyamanan (Fathoni \& Purnomo, 2015; Ilmiajayanti \& Dewi, 2015; Sari \& Wahyono, 2015), ketersediaan fasilitas penunjang (Dianty \& Dwisusanto, 2020; Fathoni \& Purnomo, 2015; Ilmiajayanti \& Dewi, 2015), dan keberagaman daya tarik pada ruang publik (Illiyin \& Idajati, 2015; Sari \& Wahyono, 2015) dapat mempengaruhi pemanfaatan ruang publik.

\section{Kesimpulan}

Alun-Alun Kabupaten Ngawi merupakan ruang terbuka publik yang dapat dimanfaatkan oleh seluruh kalangan. Faktor-faktor yang menentukan pemanfaatan Alun-Alun di Kabupaten Ngawi dilatarbelakangi oleh kondisi fisik kawasan dan perilaku pengunjung sendiri. Dari segi 
kondisi fisik kawasan, pemanfataan dipengaruhi oleh faktor kenyamanan, kestrategisan lokasi, dan daya tarik masing-masing zona. Kenyamanan dapat dilihat dari keberadaan fasilitas peneduh serta fungsi zona/ ruang yang dapat menampung beragam aktivitas. Kestrategisan lokasi dapat dilihat dari lokasinya yang dekat dengan akses pintu masuk maupun lokasi parkir serta keberadaan penjaja kuliner di sekitar zona. Sedangkan daya tarik dapat dilihat dari keberadaan atraksi pemandangan atau suasana yang dapat dinikmati pengunjung. Sementara itu, dari segi perilaku pengunjung dipengaruhi oleh faktor kebutuhan untuk beraktivitas yang nantinya akan berkaitan dengan ketersediaan waktu luang dan status hubungan sosial pengunjung.

\section{Referensi}

Anisya, I., \& Muta'ali, L. (2015). Kajian Pemanfaatan Alun-Alun sebagai Ruang Publik di Kota Cirebon. Jurnal Bumi Indonesia, 4(4), 1-4.

Carmona. (2003). Public Space Urban Space: The Didimension of Urban Design. Architectural Press.

Carr, S. (1992). Public Space. Cambridge University Press.

Dianty, G. P., \& Dwisusanto, Y. B. (2020). Aktivitas di alun-alun sebagai ruang terbuka publik dengan konsep lapangan Kasus studi : Alun-alun Bandung. ARTEKS: Jurnal Teknik Arsitektur, 5(1), 53-62. https://doi.org/10.30822/arteks.v5i1.116

Fathoni, M., \& Purnomo, A. (2015). Tinjauan Hospitality Design pada Public Open Space di Kota Semarang (Studi Kasus Taman Madukoro). Jurnal Teknik Sipil Dan Perencanaan, 17(1), 25-34. https://doi.org/10.15294/jtsp.v17i1.6889

Hakim, R. (1987). Unsur Perancangan dalam Arsitektur Lansekap. Bina Aksara.

Hantono, D. (2017). Pola Aktivitas Ruang Terbuka Publik Pada Kawasan Taman Fatahillah Jakarta. Jurnal Arsitektur KOMPOSISI, 11(6), 265-277. https://doi.org/10.24002/jars.v11i6.1360

Haryadi, H., \& Setiawan, B. (2020). Arsitektur, Lingkungan, dan Perilaku: Pengantar ke Teori Metodologi dan Aplikasi (Cet Ketiga). Gadjah Mada University Press.

Hester, R. T. (1984). Planning neighborhood space with people. Van Nostrand Reinhold.

Hilman, Y. A. (2015). Revitalisasi Konsep Alun-Alun sebagai Ruang Publik: (Studi pada pemanfaatan alun-alun Ponorogo). Aristo, 3(1), 28-37. https://doi.org/10.24269/ars.v3i1.9

Illiyin, D. F., \& Idajati, H. (2015). Faktor-faktor yang Mempengaruhi Masyarakat dalam Penggunaan Ruang Terbuka Publik sebagai Fungsi Sosial di GOR Delta Sidoarjo berdasarkan Preferensi Masyarakat. Jurnal Teknik ITS, 4(2), C114-C118.

Ilmiajayanti, F., \& Dewi, D. I. K. (2015). Persepsi Pengguna Taman Tematik Kota Bandung Terhadap Aksesibilitas dan Pemanfaatannya. Ruang, 1(1), 21-30. https://doi.org/10.14710/ruang.1.1.21-30

Indrianingrum, L., Azizah, A. N., Prasetyo, G. E., \& Hidayah, N. (2015). Pergeseran Peran Dan Fungsi Alun-Alun Kaliwungu Sebagai Ruang Terbuka Publik. Jurnal Teknik Sipil Dan Perencanaan, 17(1), 17-24. https://doi.org/10.15294/jtsp.v17i1.6887

Jamaluddin, R. (2018). Identifikasi Alun-Alun Kudus Sebagai Fasilitas Ruang Terbuka Publik Ditinjau terhadap Pendekatan Dimensi Fungsi dan Dimensi Sosial. Jurnal Planologi, 15(1), 34-48. https://doi.org/10.30659/jpsa.v15i1.2761

Noor, A., Winandari, M. I. R., \& Ischak, M. (2018). Karakter Pengguna Ruang Publik Di Taman Ayodya Jakarta Selatan. Jurnal Penelitian Dan Karya Ilmiah Arsitektur Usakti, 16(02), 60. https://doi.org/10.25105/agora.v16i02.3229

Novitasari, D. F., \& Navastara, A. M. (2017). Karakteristik Pengunjung dan Aktivitasnya Ruang Sosial di Taman Keplaksari Kabupaten Jombang. Teknik ITS, 6(2), 2337-3520.

Sari, S. R., \& Wahyono, H. (2015). Kinerja Pelayanan Alun-Alun Kota Purworejo Sebagai Ruang Publik. Teknik PWK (Perencanaan Wilayah Kota), 4(1), 1-13.

Susanti, W. D. (2015). Identifikasi Pemanfaatan Alun-Alun Malang. Envirotek: Jurnal Ilmiah Teknik Lingkungan, 7(2), 124-128. 